\title{
La evolución ideológica de Rodolfo Walsh a través de las ediciones de Operación Masacre
}

\section{The Ideological Evolution of Rodolfo Walsh through Operación Masacre's Editions}

\section{Resumen}

El presente artículo se divide en dos secciones; en la primera, se analiza el empleo de dos géneros -originalmente ajenos a la literatura canónica- en la novela Operación Masacre (1957) del escritor argentino Rodolfo Walsh: el denominado "no ficción" y el género policial. El proyecto de denuncia a partir de su contexto de producción -Argentina tras la Revolución Libertadora (1955)- condiciona el uso de dichos géneros debido a su idoneidad para vincular ficción y realidad política. Pero la denuncia no se mantiene igual a lo largo de las distintas ediciones del libro, cuya evolución va en consonancia a otros cambios socio-políticos en el seno del país. En concreto, el acercamiento de la izquierda al peronismo genera una atracción en intelectuales que, como Walsh, ven en la doctrina de Perón un modo de resistencia política frente a las injusticias del Estado. Por ello, en la segunda parte del trabajo se examina dicha evolución en los paratextos de Operación Masacre, ya que ponen de manifiesto esa aproximación de Walsh al peronismo y dan un nuevo sentido a la denuncia de su novela.

Palabras claves Operación Masacre, Rodolfo Walsh, género policial, no ficción, peronismo.

\begin{abstract}
This paper is divided into two sections; in the first, the use of two genres -originally foreign to canonical literature- is analyzed in the novel Operación Masacre (1957) by the Argentine writer Rodolfo Walsh: the so-called "non-fiction" and the police genre. The complaint project based on its production context -Argentina after Revolución Libertadora (1955)-conditions the use of these genres due to their suitability to link fiction and political reality. But the
\end{abstract}


complaint does not stay the same throughout the different editions of the book, the evolution of which is in line with other socio-political changes in the country. Specifically, the approach of the left to Peronism generates an attraction in intellectuals who, like Walsh, see in Perón's doctrine a political resistance against the injustices of the State. For this reason, in the second part of the work, this evolution is examined in Operación Masacre's paratexts since they reveal Walsh's approach to Peronism and give a new meaning to the denunciation of his novel.

Keywords

Operación Masacre, Rodolfo Walsh, police genre, non fiction, Peronism.

En la novela más paradigmática de Rodolfo Walsh, Operación Masacre (1957), convergen las tres vertientes del escritor argentino que establecen su imagen de autor viva hasta hoy': el "político/militante", el "periodista" y, finalmente, el "escritor-literato". De las tres miradas de Walsh, sin embargo, la más polémica fue la última, la de escritor-literato. Prueba de ello es la recepción de Operación Masacre hasta el día de hoy, centrada en dos ejes muy concretos: su denuncia política y su caracterización genérica al adelantarse a Truman Capote en el género de la no ficción -ya que $A$ sangre fría, el texto que inicia el género no ficcional, se publica posteriormente, en 1967-. La imagen de Walsh tiende más a su labor periodística y compromiso político que a la de escritor de ficciones; los homenajes al escritor como periodista desaparecido fueron numerosos ${ }^{2}$ : se le dedica un número especial en las revistas Texto crítico, $V$ de Vian, El matadero y Tramas

${ }^{1}$ María Teresa Gramuglio define la figura de escritor como "[...] proyecciones, autoimágenes y también anti-imágenes o contrafiguras" del mismo (37). La imagen de un autor cristaliza mediante cuestiones intratextuales, esto es, todo aquello que proyecta su producción ficcional, ensayística, paratextual, etc.; y extratextuales, es decir, su recepción y/o todas aquellas manifestaciones acerca de aspectos personales, ideológicos y políticos, divulgados en medios de comunicación. La figura de escritor determina su espacio en la tradición cultural en relación con autores coetáneos y posteriores a él; y, a su vez, condiciona su lugar en la sociedad debido a la evidente dependencia que el campo literario mantiene con otros campos -intelectual, político, periodístico, cultural, etc.La unión de ambos espacios descubre una ideología literaria del escritor y su obra, haciendo de él un tópico discursivo que se instaura en la sociedad y que restringe toda lectura de su producción literaria.

${ }^{2}$ Es significativa la sentencia de la contratapa que Ediciones de la Flor añade a la edición de 1984: "Ediciones de la Flor se enorgullece de publicar nuevamente -en edición definitiva- este clásico" (cursivas en el original) (Hernáiz 26). 
para leer la literatura argentina. De ese mito nace, por ejemplo, el Proyecto Walsh (2010), con el fin de hacer accesibles las investigaciones periodísticas del crimen denunciado en Operación Masacre ${ }^{3}$.

Pese a que la crítica especializada tendió a una diferenciación en Walsh entre la labor periodística, la producción literaria y el activismo político, la publicación de dicha novela supuso la clausura de tal separación. Como es sabido, el texto remite a sucesos reales, unos fusilamientos ilegítimos cometidos durante el golpe de Estado del general Valle en 1956. Walsh asumió la defensa del caso a través de unos artículos en prensa ${ }^{4} \mathrm{y}$, luego, narrando los acontecimientos bajo una forma genérica que, posteriormente, adquiere la denominación de no ficción ${ }^{5}$. En todo este trayecto, Walsh hará uso de su lucidez investigadora, su tenacidad para superar las barreras de la publicación y la censura, y plasmará con su prosa personal el peso de la tradición literaria, nacional y propia. En su escritura convergen, por tanto, dos campos discursivos, el periodístico y el literario. Pero, además, la toma de posición que adopta como defensor de las víctimas presume, desde un principio, una postura ética y un mensaje político que dejó huellas en el espacio textual.

El análisis detenido de Operación Masacre confirma que se pueden fusionar las tres miradas y que, a través de su escritura, el periodismo, la política y la literatura no son oficios aislados de Walsh. El presente trabajo se propone indagar acerca de tres asuntos que se entrecruzan en la novela: el género de no ficción, la

${ }^{3}$ http://proyectowalsh.com.ar/acerca-de/ (última visita el 04/08/2020).

${ }^{4}$ Para un estudio en profundidad de la labor periodística en Walsh, aconsejamos Rodolfo Walsh. El violento oficio de escribir, obra periodística (1953-1977) (2007) de Daniel Link. Por otro lado, el artículo de Roberto Ferro, “Operación Masacre: investigación y escritura” (1993-1994), ofrece una instantánea pormenorizada de estos meses de publicaciones periódicas previos a la edición del libro.

${ }^{5}$ Conviene recordar que Walsh, al escribir Operación Masacre, es pionero de un género que no había sido definido todavía. Fueron autores norteamericanos, como Hollowell, Wolf, Capote o Talesse, quienes, desde el periodismo combatiente de los años sesenta -el nuevo periodismocomenzaron a hablar de lo que ya desde entonces conocemos como la escritura de no ficción. No es menos cierto, sin embargo, que la mezcla entre periodismo y ficción - o entre realidad y ficciónpropia de este género no es nuevo en la historia de la literatura ni es una práctica que inventase el periodismo norteamericano -ya lo hacían, en cierto sentido, los cronistas de Indias, de una forma intuitiva, y posteriormente autores latinoamericanos como José Martí-. Sea como fuere, asumimos que Operación Masacre se ajusta plenamente a los rasgos con que luego se define la escritura de no ficción desde la obra de Capote, siendo esta posterior a la novela de Walsh. 
confluencia entre alta y baja cultura, y la relación con la doctrina peronista. Nuestra hipótesis es que los tres ejes condicionan la escritura y la recepción de Operación Masacre y, por ello, no puede obviarse su relación para el análisis integral del texto. Consideramos clave la evolución de sus paratextos en las cuatro ediciones que Walsh publicó en vida ${ }^{6}$. Los cambios de perspectiva ideológico-políticos del escritor guían nuestra lectura para concluir que el empleo de la no ficción y la hipotética- conciliación entre alta y baja cultura lo acercan aún más al peronismo, vínculo negado por el propio Walsh en la introducción a la primera edición: "Suspicacias que preveo me obligan a declarar que no soy peronista, no lo he sido, ni tengo la intención de serlo" (OM1 15). Con este fin, desarrollaremos previamente aspectos teóricos acerca de la no ficción, el periodismo, el género policial y la unión entre subcultura y cultura de élite; y, a continuación, explicaremos cómo las trasformaciones paratextuales de Operación Masacre proyectan la evolución del peronismo a partir del exilio de Perón en 1955.

Para ello, dialogaremos con dos estudios previos de críticos latinoamericanos trascendentales: el artículo "Rodolfo Walsh: el conflicto de culturas en Argentina" de Ángel Rama (1976), quien aborda la relación entre el conflicto de culturas (alta y baja) en Operación Masacre; y el volumen Las tres vanguardias (2016) donde Ricardo Piglia coloca a Walsh junto a Manuel Puig y Juan José Saer como los representantes de la vanguardia novelística nacional. Asimismo, partiremos de estudios anteriores vinculados concretamente a la evolución de la escritura de Operación Masacre: Sebastián Hernáiz (2012), Juan Pablo Luppi (2016), Annick Louis (2016) y Victoria García (2019). Según Hernáiz, la diferencia esencial entre los primeros paratextos y los últimos es que, si aquellos buscaban definir qué es el periodismo, los segundos buscaban establecer qué es el

${ }^{6}$ Primera Edición: Operación Masacre: un proceso que no ha sido clausurado, Buenos Aires, Ediciones Sigla, 1957; segunda edición: Operación Masacre y el expediente Livraga: con la prueba judicial que conmovió al país, Buenos Aires, Ediciones Continental Service, 1964; tercera edición: Operación Masacre, Buenos Aires, Ed. Jorge Álvarez, 1969; cuarta Edición: Operación Masacre, Buenos Aires, Ediciones De la Flor, 1972. Excluimos la denominada "edición democrática" (Hernáiz, 2012) por ser ajena a las intenciones del autor (publicada en Ediciones de la Flor en 1984). 
peronismo (Hernáiz 34). Por su parte, Luppi señala cómo el trabajo periodístico inicial termina enmarcándose en el "lugar enunciativo de las víctimas", debido a la evolución de sus paratextos (Luppi 104). Louis vuelve sobre la escritura de la novela centrándose en las versiones alternativas que el propio Walsh habría concebido y que finalmente no vieron la luz. Finalmente, el reciente estudio de Victoria García ha indagado en la evolución textual de Operación Masacre como una revisión del propio Walsh en una doble operación: generar una nueva lectura que compense el vacío ideológico de la primera edición al otorgarle al texto un alcance político. Partiendo de su premisa, leeremos ese quiebre ideológico en la escritura de Walsh a la luz de la revisión y reinterpretación que el escritor lleva a cabo del peronismo y de su propia obra, simultáneamente.

\section{La no ficción: entre la verdad de los hechos y el pacto de veracidad}

En El siglo, el filósofo Alan Badiou propone la "pasión por lo real" como una de las ideas centrales que definen el pensamiento del siglo XX en el afán por indagar en la realidad. El crítico plantea que el XX es un siglo marcado por el paradigma de la guerra y la muerte, de ahí el ímpetu bélico de la vanguardia o el compromiso político del intelectual. Tal atmósfera se proyecta de un modo particular en el ámbito hispanoamericano, un continente que vive las guerras mundiales desde la lejanía pero que sufre las intermitentes dictaduras fruto de la Guerra Fría durante la segunda mitad del siglo. En este sentido ha de leerse la siguiente cita de Walsh al afirmar que el escritor latinoamericano revoluciona el modo de profundizar en su realidad:

En América Latina el escritor realista está en la vanguardia cuando hace patente lo que esté invisible: el imperio, la lucha de clases, el sentido de las relaciones humanas y los sentimientos de los hombres. Carlos Fuentes y Vargas Llosa, el mejor Cortázar, son realismo y son vanguardia sin que haya contradicción en los términos. (Gilman 324) 
Vemos la función política y el matiz realista que Walsh le otorga a la vanguardia, de ahí que Rama lo sitúe en la generación de escritores hispanoamericanos realistas, críticos y comprometidos unidos por el periodismo (296). Es evidente que Walsh emplea una acepción de "vanguardia" que únicamente remite al impulso bélico y de avance del arte, lo que se adecua a la denuncia o el compromiso político que él cultiva. "Vanguardia" no implica, según esta definición, una experimentación formal que desvincule la ficción de lo real sino precisamente lo contrario; para ser vanguardista, según Walsh, el escritor debe visibilizar la realidad y enfrentarla al lector. Así, el periodismo se presenta como un cauce idóneo para este fin, pues habla de la realidad desde una crítica comprometida. Eso no significa que todo texto periodístico sea de vanguardia sino que el escritor puede sacar provecho del periodismo para profundizar en la realidad más inmediata, y es en ese intersticio de literatura y periodismo donde se ubica la escritura de Walsh.

Cualquier intento que nos permita un acercamiento entre literatura $\mathrm{y}$ periodismo tendrá que cuestionarse, sin remedio, el problema de vinculación de la ficción con lo real, o la unión entre lo mimético y lo ficcional. En cuanto discursos socialmente construidos, tanto el literario como el periodístico suponen una primera traición a lo real. Todo acto discursivo "ficcionaliza", por tanto, la realidad -la desvía, la reinventa, la vuelve subjetiva, la hace dependiente de una ideología o una postura estética, política, social-. Esto es algo que atenta contra toda teoría del arte como representación objetiva de la realidad -teoría mimética-, y contra los grandes discursos "auto-proclamadores de la verdad": el periodismo y la historia.

Cabe reflexionar entonces sobre el concepto de "ficción" - a pesar de que desborda los límites de nuestro trabajo- puesto que encabeza una de las dicotomías fundamentales en el campo literario. Su significación parece remitir siempre, y de manera absoluta, al ámbito de lo imaginario, fantástico. Pero, en realidad, se muestra igualmente sometido al devenir histórico y social, ya que no siempre se ha entendido de la misma manera. Las condiciones que permiten la ficcionalidad se establecen según las convenciones sociales de un período histórico determinado. 
La ficción en los textos puede medirse, por tanto, en grados, ya que en todos los textos se establece un juego de equilibrios entre el universo literario y el mundo extratextual. Mientras que, en la literatura, lo más relevante es la consistencia y la coherencia de la esfera interna del texto y sus personajes, en la no ficción, las relaciones inter-intra-extra- textuales ofrecen un movimiento más complejo en su definición. Se deben leer, por tanto, teniendo en cuenta el material real, observando las relaciones de selección y focalización a partir de esos materiales, y atendiendo a los equilibrios entre lo que no se quiere perder de vista -lo extra-textual, los sucesos sociales reales- y aquello que es inevitable reflejar -mecanismos de ficción: voz narrativa, técnicas estilistas, retórica del discurso--. Esto es esencial a la hora de analizar la obra de Walsh, puesto que su propuesta de la verdad de los hechos busca ir más allá del texto, no solo dejar constancia de su versión, sino conseguir que su versión actúe en el contexto extraliterario.

El género de la no ficción, inaugurado implícitamente por Walsh, complica aún más el problema de lo ficcional. Nosotros partiremos de la definición de no ficción propuesta por Amar Sánchez: "Los relatos de no-ficción (...) ponen en escena una versión con su lógica interna, no son una 'repetición' de lo real sino que constituyen otra realidad regida por leyes propias con la que cuestionan la credibilidad de otras versiones" (El relato 12). En la no ficción no se crea un espacio imaginario donde los datos o las personas nunca existieron, sino que se recogen documentos extraídos de la vida real. El hecho de trabajar con materiales reales no convierte al género, en este sentido, en realista. Nos apoyamos más en argumentos como el del J. Hellmann (1981), Weber (1980) y Amar Sánchez (2008) quienes sostienen que la no ficción se encuentra inmersa dentro del apogeo del experimentalismo de la década de los sesenta, una transformación, no solo en el campo de la literatura y el arte, sino a nivel social, económico y político. La famosa frase de Norman Mailer, "la realidad ya no es realista", es contundente para señalar cómo la novela realista ya no era satisfactoria para escribir sobre el mundo. Siguiendo a Hellman, las diferencias básicas entre la no ficción y la escuela realista tradicional serían las siguientes: "Relato realista: le dice al lector «todo esto no 
sucedió realmente, pero podría haber sucedido». Relato de no ficción: «todo esto realmente pasó, por tanto, no me culpen si no parece real»" (Amar Sánchez, El relato 25). Así pues, mientras que la novela realista intentaba acercarse a la representación objetiva del mundo real, parecerse a ella lo máximo posible, confundir ficción y realidad ("esto podría haber sucedido"), la proposición de la no ficción y de la ficción fantástica sería: “todo esto nunca pasó, por tanto, no me culpen si no parece real"). Es decir, no se intenta que parezca real, destruyendo así la ilusión de representación fiel. La premisa básica de un material que debe ser respetado tiene una consecuencia directa en relación con el referente del texto y su pacto de lectura. El lector exige al texto una verificación que, de no cumplirse en sus aspectos esenciales, transgrede la condición nuclear del género. Si la referencialidad de la no ficción es una, real y, en consecuencia, extraliteraria, ello determina tanto el horizonte de expectativas como el pacto de lectura del receptor, quien se acerca al texto condicionado por el conocimiento previo que posee de aquello que se cuenta. El lector espera una correspondencia entre los hechos narrados y la historia verídica. De esta forma, podríamos denominar "pacto de veracidad" a la actitud con la cual todo sujeto lee una obra de no ficción. Tal pacto se inicia, al igual que el horizonte de expectativas, desde elementos que rodean el libro -título, paratextos, declaraciones del autor, lecturas e interpretaciones ajenas, y se comprueba según el modo en que se relata el acontecimiento en cuestión instancia narrativa, fidelidad a los hechos, verosimilitud de la trama, etc.-. La condición inherente de la no ficción atañe tanto a la mímesis como a la diégesis textual: se "imitan" unas acciones pasadas (mímesis), y la experimentación formal no debe ir contra la credibilidad del lector. Es decir, es un género dialéctico donde mímesis y diégesis conviven, sin que uno se superponga al otro. Dicho de otro modo: al ser literario, el género admite cierta creatividad, desviaciones, añadidos o eliminaciones, que intensifican el interés de su lectura, siempre y cuando no contradigan ni rompan la veracidad de la historia. 


\section{La no-ficción en la literatura argentina}

Como es sabido, la literatura hispanoamericana se inicia en manos de intelectuales y políticos que buscan configurar una cultura en las nuevas naciones emergentes. De ahí que su relación con la realidad sea, como explica Jitrik, o de "representatividad" - para proyectar las costumbres del pueblo-o de "legitimidad" -para establecer criterios que sustenten un canon nacional-. En nuestra opinión, las líneas mencionadas nunca se presentaron separadas pues, antes bien, los escritores perseguían el afán representativo y el resultado fueron obras que legitimaran una tradición nacional. Por ello, ambas corrientes no solo se concilian en El matadero, como apunta Jitrik, también se fusionan en un texto cuya relación con la realidad extratextual es especialmente compleja, Facundo. Como explica Piglia, Sarmiento lleva a cabo un uso político de la literatura prescindiendo de la ficción, desde el cual parte Walsh ${ }^{7}$ (Las tres vanguardias 173). De ahí la siguiente declaración de Walsh al aludir a la función del arte comprometido en 1970: “...yo creo que la denuncia traducida al arte de la novela se vuelve inofensiva, es decir, se sacraliza como arte" (Piglia, Las tres vanguardias 173). La cita justifica la elección del género de no ficción en Operación Masacre con el fin de denunciar una situación real o, en términos de Jitrik, representar una situación real para deslegitimar una injusticia sistemática: la violencia del Estado dirigida a quien debe proteger. En otras palabras, Walsh señala "aquello que no debe ser" con relación a la actuación estatal y el mensaje de Operación Masacre sería la paradoja indicada por Piglia: "lo imposible es verdadero":

Operación Masacre: narrar un hecho real como si fuera ficticio, haciendo saber siempre que se trata de un hecho real. [...] Es el hecho verdadero que parece ficcional lo que funciona como material de la no ficción.

\footnotetext{
${ }^{7}$ Rita De Grandis: “[...] las ejecuciones de Operación Masacre refuerzan una práctica política fundadora de uno de los rasgos de la identidad literaria argentina: la del caudillo asesinado. [...] No olvidemos tampoco que el primer relato nacional, El matadero (1837) evoca por su título mismo muertes sangrientas. En otras palabras, esta productividad textual nos lleva a interrogarnos acerca de la seducción de un texto artístico construido sobre la repetición de un suceso sangriento" ("Entre la escritura": 309).
} 
[...] Operación Masacre está construida sobre la base de la tensión entre el hecho de que lo imposible es verdadero [...] y el hecho de que lo verdadero es inverosimil. (Piglia, Las tres vanguardias 201) (cursiva nuestra)

La siguiente cita de Operación Masacre ilustra el apunte de Piglia: "A Benavídez va a sucederle algo increíble, algo que aun ubicado en esa noche de singulares aventuras y experiencias parece arrancado de una exuberante novela" (Walsh, Operación [ed. 2008] 85). La cursiva es nuestra para destacar cómo, en este sentido, la no ficción se contrapone al género fantástico, cuyas premisas son: "lo imposible no es verosímil" pero se admite según el pacto de ficción acordado entre autor y lector. Operación Masacre, por el contrario, señala lo inverosímil de la realidad empírica y su pacto de lectura no exige entonces credibilidad sino veracidad. Por tanto, además de inaugurar el género de no ficción en Argentina, Walsh revierte la fórmula de los escritores decimonónicos pues, como explica Viñas, la denuncia de los románticos era simétricamente opuesta: "[...] si en Echeverría y en Mármol se producía desde los de abajo hacia el cuerpo y la vivienda de los señores, en 1977 se ejecuta desde el Poder en dirección a un escritor crítico"8 (258).

En Operación Masacre, Walsh fundirá no solo las dos líneas propuestas por Jitrik -representatividad y legitimidad- sino también la realidad y la ficción, y las culturas popular y hegemónica. Tales dicotomías tienen una fuente en la literatura decimonónica, concretamente en obras de Hernández, Sarmiento, Echeverría y Mansilla. Los mencionados comparten una profesión que es central con respecto a la relación ficción y verdad: el periodismo. Iniciado el siglo XX, unos de los escritores argentinos más involucrado entre el periodismo y la literatura es Roberto

\footnotetext{
${ }^{8}$ Viñas considera que Operación Masacre sigue una tradición inaugurada por José Hernández y continuada por Arlt -en su descripción del fusilamiento de Severino Di Gionvanni en 1931-: "Esos momentos portan tres blasones que corroboran las complejas y mediadas pero decisivas relaciones entre la política argentina y el espacio textual: la liquidación del gaucho rebelde, la eliminación del inmigrante peligroso y la Masacre del obrero subversivo" (Literatura 249).
} 
Arlt, cuya obra posee una estrecha vinculación con la novela de Walsh. La relación entre la producción periodística y literaria es apuntada por el mismo Arlt -por ejemplo, en la nota explicativa que abre el drama 300 millones, donde aclara que su argumento está basado en un suceso real que él conoció gracias a la colaboración en Crítica-. Pero, aún más importante para el tema que nos ocupa, sería el final de Los lanzallamas, donde se exhibe una denuncia directa a la separación entre realidad e información; en palabras de Piglia:

En este final de Arlt, entonces, se abre el debate sobre el estado actual de la narración en una sociedad definida por la circulación demencial de información. La novela como género problematiza la información y también la distinción verdadero/falso a la que convierte en tema de la narración ${ }^{9}$. En síntesis, los medios de masas exponen a los ciudadanos a un exceso de noticias y la novela los defiende, reduciendo la información y estableciendo un campo manejable de indicios. (Las tres vanguardias 92-93)

Esa defensa de la "novela por la verdad" es Operación Masacre: escribir ficción a través del género novelístico, pero con el afán de veracidad del periodismo. La novela de Walsh mantiene una dependencia explícita con la verdad porque posee una función concreta en un contexto histórico-político determinado. Su lectura está condicionada a una situación que se quiere denunciar y, aislada de ese contexto, pierde todo su sentido.

\footnotetext{
${ }^{9}$ Esta afirmación requiere de un matiz aclaratorio: aunque Piglia se refiera a Los Lanzallamas, es una característica de la novela moderna desde el Quijote: hacer del vínculo falso/real el argumento de su narración. Lo que varía es el modo de señalar la problematización de su unión y, en este aspecto, el periodismo viene a cubrir un espacio nuclear del cual Walsh saca provecho.
} 


\section{Un crimen sin castigo. El género policial en Operación Masacre}

Rama considera que la obra de Walsh es el culmen de la asociación entre cultura elevada y subcultura en la literatura argentina, una unión que se alcanzaría mediante el uso del periodismo y del género policial -considerados subculturalescomo alta literatura -algo que harán posteriormente Capote, Wolfe y Norman Mailer desde Norteamérica-. Al practicar la novela de no ficción, Walsh -dice Rama- da un paso más pues se sirve del género policial con un fin de denuncia directa, ausente en la producción de Borges o de Bioy Casares ${ }^{10}$. Así, si la renovación de Borges es estética, pero fundamental al fundir ese conflicto de culturas, Walsh parte de esa convergencia para colocarse a la vanguardia política nacional, lo que condiciona la caracterización genérica de Operación Masacre debido a su pulsión con la verdad. En palabras de Piglia:

¿Cómo se construye lo real en la ficción [...]? En el género policial. Se cuenta la construcción del hecho verdadero en contra del hecho falso [...]. Y entre literatura fantástica, policial y periodismo hay un cruce: todas estas prácticas se preguntan qué es un hecho. (Las tres vanguardias 198)

La no ficción y la narrativa policial comparten orígenes similares y un espacio abiertamente contra-hegemónico dentro de la tradición literaria canónica. Son géneros masivos cuyo estatuto siempre resulta cuestionado: puede considerarse un agente alienante, sujeto a las leyes del mercado editorial y, por tanto, de estructura esquemática y repetitiva; o, por el contrario, se concibe como resistencia a los medios de producción de masas. La tipología más extendida del relato policial distingue la novela de enigma clásico frente a la serie negra. Junto a Rama, Aníbal Ford (1974) ha señalado la frontera entre la primera época de Walsh y la segunda, marcada por el paso del enigma clásico al relato de compromiso social. El crítico

${ }^{10}$ Recordamos que ambos son responsables de la difusión del género en el país, no solo a través de su propia obra ficcional, sino también mediante la fundación de El Séptimo Círculo -colección editorial de obras policiales-, o la publicación de Los mejores cuentos policiales argentinos (1943). 
declara que las novelas de no ficción se oponen a la literatura policial del Walsh anterior y, por tanto, a la herencia de Borges; Ford establece así la oposición Walsh/Borges, mientras que Rama sí reconoce en Walsh a un discípulo heterodoxo de Borges y también defiende la presencia del elemento policial como una constante en su obra. No obstante, sugiere la distinción en los relatos de no ficción a los cuales denomina "novelas policiales para pobres"11 (Rama 299). Amar Sánchez (2008) propone una alternativa más conciliadora, abogando por la presencia de similares mecanismos constructivos que recorrerían todos los textos de Walsh, desde sus inicios hasta los no ficcionales.

Nosotros nos posicionamos a favor de Ford en tanto consideramos que el policial de Walsh se distancia de las tramas típicas borgianas porque su intriga se aleja del suspense meramente ficcional borgiano ${ }^{12}$. Pero la diferencia esencial está en el desajuste de intereses: los textos de Borges carecen de la denuncia de Operación Masacre y, por tanto, de la carga ideológico-política que Walsh le otorga a la novela. Asimismo, tampoco coincidimos con Rama en que Walsh alcance la conciliación entre dos culturas enfrentadas -alta y baja-. Por un lado porque, al servirse del género policial, Walsh parte de una revolución estética, realizada previamente por Borges, de asociar ambas culturas al darle al género policial un estatuto elevado; no lleva a cabo, por tanto, una innovación relevante en un sentido artístico. En relación al periodismo y la no ficción, nos alejamos de la tesis de Rama porque no creemos que su uso implique un acercamiento a la subcultura ya que el asunto tratado en Operación Masacre posee una complejidad

\footnotetext{
${ }^{11}$ No compartimos dicha denominación que, además, Rama no se preocupa en delimitar. Inconscientemente, el crítico parece contagiarse del vocabulario peronista al considerar "pobre" al público (peronista) a quien Walsh parece dirigir su texto, como veremos en relación con el lector ideal de la novela.

${ }^{12}$ Sí encontramos cierto influjo de la sintaxis borgiana como la sentencia que clausura "Díaz: dos instantáneas": "Lo único preciso [...] es su aspecto físico, un hombre corpulento [...], que en un momento estará jugando con entusiasmo al chinchón, y en un momento muy distinto [...] roncará apaciblemente. [...] En estas dos instantáneas puede resumirse toda la vida de un hombre" (Walsh, Operación [ed. 2008] 41-42). O en la siguiente cláusula: "Ya no hay sindicato ni hay delegado. Entonces comprende que él es nadie, que el mundo pertenece a los doctores" (Operación [ed. 2008] 64). Y finalmente, en algunas expresiones de tono literario: "[...] y un alarido aterrador, que perfora la noche y parece prolongarse hasta el infinito" (cursivas nuestras) (Operación [ed. 2008] 123).
} 
política que no está al alcance de todos - a pesar de que el proyecto original de Walsh pudiera dirigirse a un amplio abanico de lectores-. Esto es, aunque Walsh quería que el esclarecimiento y la denuncia de los hechos llegase al conocimiento del mayor número de personas posibles, tales acontecimientos se entretejen en una trama que difícilmente podían comprenderse fuera del contexto específico de la política nacional argentina. Ello convierte a Operación Masacre en un libro de lectura acotada y alejado del consumo de masas, pues su escritura se vuelve, por momentos, muy técnica.

\section{Conspiración y peronismo: metralletas contra libros}

En El habla de la ideología (1989) Andrés Avellaneda explica en detalle el proceso del desarrollo del género fantástico y el policial durante los años cuarenta en Argentina. Debido a su eficacia para denunciar oblicuamente una situación política o ideológica, escritores contrarios al peronismo se sirvieron de ambos géneros para denunciar el supuesto accionar ilícito por parte de órdenes estatales que, antes de proteger al individuo, iban contra él ${ }^{13}$. La traición y la conspiración funcionan en los relatos borgianos, por ejemplo, como denuncia a todo nacionalismo ${ }^{14}$; por tanto, leídos en su contexto histórico-político, la crítica apunta directamente al peronismo ${ }^{15}$. Ahora bien, la doctrina de Perón evoluciona favorablemente desde sus inicios en los años treinta hasta su derrocamiento en 1955, sobre todo, en su relación con la izquierda. En su origen, Perón tenía un apoyo directo por una gran mayoría del clero y, por lo tanto, movimientos anarquistas, comunistas y socialistas se oponían radicalmente a su régimen. Pero ya desde su primera presidencia, comienzan las tensiones con la Iglesia, y su defensa al obrero

\footnotetext{
${ }^{13}$ Un ejemplo paradigmático, luego olvidado, fue la novela de Payró, El estruendo de las rosas (1948).

${ }^{14}$ Para un examen más detallado sobre el tema, consultar "Borges nacionalista" (2011) de Jorge Panesi.

${ }^{15} \mathrm{El}$ género fantástico emplea otras estrategias retóricas, pero también se han hecho lecturas políticas del mismo a raíz del peronismo. En "Casa tomada" (1946) de Cortázar, el semema de la invasión remitiría a la sensación de asedio percibida por los antiperonistas frente a la aparición repentina de un sector de la sociedad inexistente hasta entonces: el trabajador implicado en cuestiones políticas.
} 
y a la clase media acerca a muchos intelectuales de izquierda al peronismo. Este largo y complejo proceso posee consecuencias directas en la literatura: el campo literario de los años cuarenta adquiriere una autonomía que no tenía en la década anterior ${ }^{16}$ pues, aunque el trasfondo de sus obras posea matices políticos o ideológicos, la apuesta por renovar el sistema literario es el propósito principal de estos escritores. Dicha situación se verá revertida a partir del derrocamiento y exilio de Perón, en septiembre de 1955, que impone el programa cívico-militar de la Revolución Libertadora - con Aramburu y el vicepresidente Rojas a la cabeza-, y el fracaso de la revolución de Valle, en 1956. El propio Walsh ya apuntaba las causas de esta oposición a Perón, en una carta a su amigo Donald Yates, en 1957:

En el aspecto cultural, Perón revela una inagotable torpeza. Se gana la abierta hostilidad de los intelectuales, aun de los llamados "escritores sociales" $[\ldots]$ censura, molesta, prohíbe, persigue [...] durante el peronismo gozaron de libertad y democracia los sectores obreros; en cambio se sintieron oprimidos la clase media, los intelectuales, los artistas, periodistas y la clase alta. (Link, Ese hombre 35-36)

Con esta reflexión Walsh se incluía entre el grupo de intelectuales beneficiados por el cambio de régimen. Cristaliza en él la figura del escritor procedente de la cultura dominante -aunque de forma incipiente, pues aún trataba de hacerse un hueco en el panorama intelectual- que en los años venideros girará hacia las filas del peronismo. Operación Masacre supone en este sentido, un texto paradigmático porque, si bien se publica cuando Walsh aún postula una tendencia antiperonista, las sucesivas ediciones muestran el cambio ideológico del autor $\mathrm{y}$, a su vez, la problemática estética que conlleva este cambio. La victoria de Fidel Castro y el Che en el 59, unido a las expectativas frustradas del gobierno de

\footnotetext{
${ }^{16}$ Los años treinta se caracterizaron por una unión entre el campo intelectual y político, ya que los anteriores miembros de la vanguardia se involucran en cuestiones que atañen al nacionalismo emergente, a la entrada del comunismo y socialismo al país, o a los acontecimientos acaecidos en Europa -guerra civil española y II Guerra Mundial-.
} 
Aramburu, promovieron el interés por una verdadera revolución socialista. El intelectual, entonces, se ampara bajo un "concepto-paraguas", el de compromiso ${ }^{17}$, conformándose así lo que Gilman denomina la "ideología de la escritura", o concepción de la palabra como elemento peligroso y opositor del Estado (Gilman 74). Esta primera etapa finaliza en torno a 1966 cuando la figura del intelectual empieza a ser puesta en cuestión a favor de un nuevo tipo de intelectual verdaderamente revolucionario. Es decir, no solo bastaba con promover un tipo de literatura comprometida, sino que se hacía necesario que el escritor ocupara una zona de relevancia social que autorizara su obra. Ante esta disyuntiva se producen al menos dos respuestas. Primero, un férreo antiintelectualismo entre los propios intelectuales, quienes consideraban que había que tomar las armas y dejar apartada la palabra a favor de la militancia política. La otra postura defendía que el acto de escribir podía ser una amenaza para las fuerzas antirrevolucionarias. Sirva de ejemplo la posición que asume Walsh al final de la introducción a la primera edición de Operación Masacre: "Espero que no se me critique el creer en un libro [...] cuando son tantos más los que creen que las metralletas" $(O M 117)^{18}$.

En medio de dicha atmósfera, Perón simboliza la resistencia militante y política frente a quienes tomaron el poder de manera ilegítima. La lectura que del peronismo se hace a partir de su derrocamiento sirve para estrechar sus vínculos con la intelectualidad de izquierda, creando la fórmula Perón-trabajadores versus políticos. El discurso peronista había sido muy elocuente desde sus inicios mediante

\footnotetext{
${ }^{17}$ La noción de "compromiso" era deliberadamente abstracta y no contaba con un programa de acción concreto. La pertenencia a la izquierda fue elemento crucial para legitimar la labor intelectual, y el intelectual progresista sirvió como término aglutinador de críticos, ideólogos, artistas o escritores. Por supuesto, tales adscripciones no solo se justificaban por el contexto histórico pre-revolucionario sino también por el apoyo a la causa de ciertas presencias poderosas dentro del panorama cultural, como Jean-Paul Sartre, especialmente su libro ¿Qué es la literatura? (1948) donde forja la noción de compromiso (engagement), o, anteriormente, Antonio Gramsci, que postuló la relación entre los intelectuales y las masas.

${ }^{18}$ Esta idea la desarrolla con más detalle en una entrevista con Piglia (1970): "Vos viste que desde la derecha no hay ningún problema para seguir haciendo literatura. Ningún escritor de derecha se plantea si en vez de hacer literatura no es mejor entrar en la Legión Cívica. Solamente se plantea el problema de este lado; entonces vos tenés que hablar, tenés que decir eso con los escritores de izquierda. Hay un dilema. [...] hasta que te das cuenta de que tenés un arma: la máquina de escribir" (Walsh "El periodismo" [s,p.]).
} 
lo que Sigal y Verón denominan el "vaciamiento del campo político": Perón se dirige al pueblo como su aliado al tiempo que se refiere al político como el enemigo. Así, se presenta en sociedad sin el estatuto de político al crear la equivalencia entre Perón y pueblo, y colmando de connotaciones negativas al político, a quien considera enemigo de la patria (Sigal y Verón 70-73) ${ }^{19}$. De su discurso se desprende la ecuación nacionalista que más relevancia cobrará posteriormente: peronismo equivale a Argentina y, por tanto, todo enemigo de Perón lo es también de la patria ${ }^{20}$. Por ello, la Revolución Libertadora y su derrocamiento, se viven en el país como una violencia ejercida por la política contra el pueblo y no como una lucha entre dos bandos equivalentes ${ }^{21}$. Como explica Alberto Julián Pérez, la Revolución Libertadora supuso que el peronismo alcanzara por primera vez un sentido revolucionario: "Las ideas sobre el peronismo cambiaron durante la Resistencia cuando se transformó en un movimiento perseguido y proscripto" (14). Ese hecho, el exilio de Perón y la influencia de la Revolución Cubana, dan cabida a un nacionalismo de izquierda que se inicia en los cincuenta y que pervive hasta hoy.

En este contexto, Walsh se acerca al peronismo y se entiende su viraje literario hacia la no ficción con un objetivo de compromiso político. El realismo convencional se percibía como algo anticuado, por lo tanto, no era compatible con la defensa de la postura revolucionaria de la ruptura; pero tampoco se podía dar la espalda a la narrativa del Boom, que estaba formulando un nuevo tipo de novela totalizadora, social y experimental a la vez. Se empezó a hablar, por tanto, de una

\footnotetext{
${ }^{19} \mathrm{El}$ peronismo se definía a sí mismo, no como ideología, sino como doctrina que permite, acoge y respeta todo tipo de ideología política. Así se explicaría la clave de su éxito y la razón por la cual intelectuales católicos y conservadores como Marechal compartan la misma doctrina con peronistas de izquierda, como Walsh.

${ }^{20}$ Recordamos el ensayo Los vendepatria de 1957.

${ }^{21}$ En este sentido, debemos leer Operación Masacre como una denuncia en consonancia con el ideologema más relevante de la literatura argentina, la dicotomía civilización y barbarie. Veremos más adelante cómo la denuncia de Walsh se asimila a la de El matadero de Echeverría: la violencia ejercida desde el Estado hacia el individuo, la barbarie como autoridad. Tal asimilación se observa explícitamente al denominar "carnicería" a la matanza: "A su alrededor se dilatan infinitamente los ecos de la carnicería" (Walsh Operación [ed. 2008] 125); pero aún más en el final a "El tiempo se detiene": "Lo que ocurrió a partir de entonces es todo un capítulo en la historia de nuestra barbarie" (Ibid. 127).
} 
definición más amplia de "realismo" -siguiendo la propuesta de Brecht-, un "realismo vanguardista" o "nuevo realismo". A favor de esta idea, escribe Walsh:

Realismo no se opone necesariamente a vanguardismo. Cuando el agotamiento de temas o de formas debilitan la pintura de la realidad y su interpretación, el autor realista se vuelve por fuerza vanguardista. La vanguardia es entonces el modo que asume el realismo en una coyuntura histórica de agotamiento. Esa coyuntura no se puede forzar [...] cuando se lo intenta a contrapelo el resultado es siempre anomalías o rarezas que momentáneamente pasan por vanguardia. (Gilman 324)

Así, se inicia un nuevo proceso de revitalización de géneros y formatos literarios o paraliterarios que pudieran servir como vehículo explícito para la revolución: el testimonio, el periodismo, la canción protesta, la poesía y sobre todo el cine político. Entendiendo las claves de este debate en un intersticio entre política y estética, se vuelve más plausible detectar que ciertas ambivalencias de la escritura de Walsh son, en realidad, producto de la búsqueda de un discurso literario desde poéticas combatientes, más que de una renuncia a la ficción en pos de la toma de las armas. Conviene recordar que Operación Masacre se publica por primera vez al menos diez años antes de que se postulasen estos programas estéticos renovadores, y se abogase por el empleo del género testimonial y la mezcla con el código periodístico, lo que convierte a Walsh en un auténtico pionero de las propuestas futuras.

\section{Hacia el libro: la campaña periodística}

La primera fase de la escritura periodística acerca de los fusilamientos de León Suárez en 1956 se realiza en algo más de doce meses, entre el 25 de diciembre de 1956 -cuando aparece la primera nota en prensa-y marzo de 1958 -después de publicada la primera edición del libro-. Los artículos aparecen en los diarios Propósitos, Revolución Nacional y Mayoría; son quince textos en total que dan 
forma a la historia, simultaneados con el propio proceso judicial. El objetivo principal de Walsh es que el proceso se sepa para proteger a las víctimas del silencio institucional, pero eso no va a impedir su deslizamiento hacia otras formas discursivas, esencialmente, el lenguaje judicial y el literario. "Castigo a los culpables", la primera nota publicada en Propósitos, más que una crónica, es la reproducción exacta de la denuncia de Livraga ante los tribunales. La resaltamos aquí no solo por ser el germen de todo, sino por haber iniciado las pautas que se encauzarán luego en la novela. Este recurso al código judicial inaugura en Walsh una obsesión que se va a traspasar al libro y permanecerá en todas las ediciones. Los casos en que la voz narrativa busca desaparecer por completo dejan lugar al lenguaje jurídico, telegráfico o radiofónico. Estas tres vías marcan los puntos de fuga de lo literario, la huida, en momentos clave, del aparato estilístico ${ }^{22}$. Aquí, no obstante, la voz del narrador no desaparece del todo; el periodista no se resiste a explicitar su sentencia moral, y la sitúa además en el centro físico de la denuncia, subrayada por un marco gráfico que hace las funciones de límite fingido entre las voces narrativas. Walsh propone así una ilusión de objetividad que él mismo se encarga de frustrar. Tomando la voz de Livraga, asume la posición de las víctimas $^{23}$, pero el cuestionamiento hondo a los aparatos estatales represivos solo se apreciará someramente en esta primera etapa. Esta circunstancia no es en absoluto anecdótica y nos da las claves para analizar el cambio ideológico que se va a producir en Walsh: aquí aún se percibe una cierta confianza en la justicia, en el gobierno de Aramburu. El periodista todavía confía en que estos altercados hayan sido hechos aislados, promovidos por el caos del levantamiento, y solo reclama la toma de responsabilidades individuales. La apelación a la justicia como ente

\footnotetext{
${ }^{22}$ Este procedimiento nos sirve para reflexionar acerca de una de las cuestiones más polémicas de Operación Masacre, sobre la que no hay una visión clara entre los investigadores. Si, por un lado, Walsh busca desenmascarar la pretendida objetividad de los discursos oficiales, enfrentándolo al valor de las versiones, no deja de sorprender cómo recurre también a los mismos cuando quiere mostrarse portador de la verdad.

${ }^{23}$ Esto enlazaría con algunas consideraciones en torno a la escritura testimonial que concibe que el testimonio debe situarse en la posición de los marginados, como versiones contrarias al discurso oficial, y que, por el contrario, una literatura testimonial apadrinada por el Estado cae irremediablemente en fórmulas dogmáticas. Véase Elzbieta Sklodowska, Testimonio Hispanoamericano: historia, teoría, poética (1992).
} 
supremo que restituye el dolor de las víctimas se aprecia, primero en el título, "Castigo a los culpables" -sin explicitar quiénes son los culpables- pero también en la sentencia final, donde en letras mayúsculas, leemos: “proveer de conformidad SERÁ JUSTICIA”. Se revela aquí una postura política aún a medio hacer; se apela a la Justicia pero se calla en relación con todo lo demás.

Entre esta primera publicación a la segunda, editada en Revolución Nacional con poco margen de distancia temporal, se puede apreciar un cambio cualitativo en los giros discursivos. El título de la nueva nota, "Yo también fui fusilado", vuelve a presentar una de las claves interpretativas: la subjetivación del discurso a través de la presencia de la voz narrativa que quiere confundirse con las víctimas y asumir el mismo discurso. El "yo" de la forma personal se enfrenta a la objetividad del código periodístico y revela el filtro de la elaboración textual. Pese a que Walsh destierra el uso tan marcado del lenguaje jurídico que había empleado en "Castigo a los culpables", sigue acudiendo, en la organización estructural, a “...la oratio judicial, de acuerdo a cómo la codificaba la retórica clásica" (Ferro 150). Esta estructuración constaría de: 1) Una primera parte donde se apela a la atención del tribunal: un exordio, que abre la exposición, y un epílogo que la cierra. 2) Una segunda parte o cuerpo textual que se compondría de la narratio de los hechos y la confirmatio o establecimiento de las pruebas. En efecto, Walsh habría solucionado aquí el problema de la vertebración de Operación Masacre, que, pese a que en las sucesivas ediciones va a ir añadiendo colorarios y apéndices, en lo esencial mantendrá esta forma: Prólogo- Cuerpo Textual- Epílogo. Lo siguientes artículos publicados en Revolución Nacional van a continuar con esta misma línea de denuncia y exposición de las pruebas incriminatorias. No obstante, ya sobre el mes de marzo, se va estableciendo la idea de escribir un libro ${ }^{24}$. Finalmente, el 12

\footnotetext{
${ }^{24} \mathrm{El}$ proyecto de publicación pasa por las manos de Noé Jitrik, pero finalmente es asumido por los editores de Mayoría, los hermanos Jacovella. No obstante, la novela sale a la calle en forma seriada, en un total de nueve notas, en Mayoría, entre el 27 de mayo y el 31 de julio. El relato de los sucesos, las denuncias y las pruebas se desarrollan en las ocho primeras bajo el subtítulo "Un libro que no encuentra editor"; la novena nota sale el 31 de julio con el nombre de "Obligado Apéndice". Debido a la publicación fragmentada, se pueden explicar las similitudes que encontramos entre los remates de muchos capítulos del libro y la estructura del folletín.
} 
de diciembre de 1957 -casi un año después de aquellas primeras palabras "Hay un fusilado que vive"- aparece la primera edición unificada del libro con el título: Operación Masacre, un proceso que no ha sido clausurado.

\section{Prólogos de Operación Masacre}

En palabras de Rita de Grandis, los prólogos de Operación Masacre "[...] contienen la historia de su propia escritura" (Grandis 112). Asimismo, proyectan la propia evolución discursiva implícitamente desde el primero hasta el definitivo. Por ello, Hernáiz indica que el paratexto de Operación Masacre se constituyó como un "variable organizador de sentido", lo que le lleva a concluir que no es Walsh quien da su sentido último a la novela, sino las varias lecturas suscitadas de los paratextos (24). Esa zona inicial del paratexto es, para Walsh, el lugar idóneo para reflexionar sobre la propia elaboración en la escritura y su interacción con los testigos y lectores. El paratexto inicial de la primera edición en 1957 (OM1) está compuesto de: dos epígrafes, uno literario -cita de T. S. Eliot- y otro judicial -declaración de Rodolfo Rodríguez Moreno, jefe de la Unidad Regional que recibe la orden de fusilamiento-; un prólogo, y una introducción de marzo de 1957. Lo primero que percibimos al leer estos textos es que aún el espacio no está definido en sus características literarias. Es decir, la tendencia es, a menudo, la de encubrir los términos estéticos, sobrevalorando los comunicativos, el mensaje final. Se busca, más bien, un golpe de efecto en la opinión pública y los lectores a través de discursos propagandísticos. Así, apreciamos la obsesión de Walsh al reivindicar el carácter funcional del libro; leemos en el prólogo de 1957:

Escribí este libro para que fuese publicado, para que actuara, no para que se incorporase al vasto número de las ensoñaciones de ideólogos ${ }^{25}$. [...]

\footnotetext{
${ }^{25}$ La cursiva es nuestra para explicar la alusiva referencia de Walsh a la serie de intelectuales que intervinieron en el debate acerca del valor de la Revolución Libertadora. Entre ellos destacan Martínez Estrada en Propósitos (10/07/1956), quien se queja de la acusación de peronista que Borges lanzara hacia él por atacar la Revolución. Desde Sur $(242,1956)$, Borges responde a Martínez Estrada y reafirma su apoyo a la misma: “[...] el régimen de Perón era abominable, que
} 
Quienquiera que me ayude a difundirlos y divulgarlos es para mí un aliado a quien no interrogo por su idea política. (OM1 9)

Esta aparente neutralidad demuestra aún un cierto titubeo político que se materializa en una crítica somera y parcial. Todavía la Justicia se erige como bien supremo no contaminada por los poderes políticos. Los mecanismos de ficción no quieren ser ocultados de forma contundente en la escritura de Walsh - a pesar de las numerosas proclamas sociales-. Si bien nos desvela los procedimientos de la investigación, tiene continuamente tentativas de proclamarse como portador de la única verdad posible ya que la autoridad de la voz narrativa frente a la voz del Sistema es explícita. La narración se va a producir siempre en primera persona, recurriendo por momento a técnicas del discurso autobiográfico, contagiado por el discurso indirecto libre. Un prólogo, por tanto, que justifica la presencia del "yo" en relación con su obra y con los problemas de escritura, y que vincula directamente al autor con el narrador.

El prólogo y la introducción de la segunda edición no registran cambios pero, posteriormente, únicamente permanece el epígrafe literario y desaparece el judicial. Esto, junto a otras reformulaciones en el epílogo y el cuerpo textual, nos indican que quizá sea la edición de 1964 (OM2) la más intencionadamente literaria, aunque no la más conseguida. La tercera (OM3) se publica en 1969, cuando Walsh milita en el sindicato argentino, la $\mathrm{CGT}^{26}$ (Jozami, 2011), y donde fija la forma definitiva del prólogo, estableciéndose el paratexto inicial sin el epígrafe literario ni la introducción. Este nuevo prólogo se muestra como el punto de encuentro de técnicas ya empleadas y, a su vez, destierra el discurso más propagandístico y panfletario, siendo el más logrado a nivel estético. En términos de Jakobson, la función conativa -o de persuasión- deja paso a una función más bien poética. No

la revolución que lo derribó fue un acto de justicia y que el gobierno de esa revolución merece la amistad y la gratitud de todos los argentinos" (Borges 72).

${ }^{26}$ Tras su viaje a Cuba, en Argentina funda y dirige el semanario el semanario de la CGT de los Argentinos, entre 1968 y 1970, y que luego pasará a publicarse de forma clandestina. En 1970, empieza a relacionarse con las Fuerzas Armadas Peronistas (FAP), y, finalmente, comienza a militar en Montoneros, con quienes empieza a tener diferencias políticas a partir de 1974. 
es paradójico que elimine aquí el epígrafe de T.S Eliot y lo reemplace por un fragmento de la declaración del inspector Rodríguez Moreno; no lo hace por borrar la literariedad textual sino más bien por una sustitución de autoridades: la suya a cambio de aquella que está desahuciando. Este será el espacio autorizado del orador: el texto recrea en pasado todo el proceso de investigación, sacando a la luz hechos que había descartado en ediciones anteriores, lugares y decisiones a las cuales ahora recurre porque van hilando la narración de la escritura y sustituyen aquello que anteriormente habían sido proclamaciones ideológicas. Pareciera que, de alguna manera, se claudica hacia una relativización de ese mensaje que tan intensamente quería propagar en las dos primeras ediciones. Cabe reflexionar, además, sobre cómo afecta esto a la caracterización genérica de la novela pues, si todo prólogo condiciona el horizonte de expectativas del cuerpo textual, la diferencia entre el primero (más documental) y el tercero (más literario) incide en el modo en que se leerá la novela. Tras el último prólogo, la obra tiende hacia una subjetividad que la aleja de la no ficción. No obstante, si el prólogo se reviste con fingida humildad, es porque tiene previsto, en el epílogo, usar todo el arsenal documental -que él considera más efectivo- para persuadir al tribunal y a los lectores, que son, como veremos, equivalentes.

\section{Los epílogos}

En el prólogo, el autor-narrador pone todo su empeño en captar la atención del tribunal -a quien simula exponer el caso-, y conseguir así la predisposición del lector para aceptar como verdadera la historia que se narra. El epílogo, según esta misma lógica, vendría a cumplir idéntica función que el prólogo -aunque al estar al final de la novela, carece de ese efecto anticipatorio-. Si bien aceptamos que prólogo y epílogo son los espacios donde el narrador quiere establecer un mayor diálogo con los lectores, ambas partes, en Operación Masacre, cumplen roles diferentes y van a evolucionar en direcciones distintas. Frente a los prólogos, estructurados en torno a una narración cerrada y muy marcada, los epílogos tienden 
a mezclarse y confundirse con la última parte de la narratio, llamada "La evidencia".

Los epílogos son textos más parecidos a la escritura en prensa de la primera etapa por su alejamiento del tono literario y su carácter periodístico-infomativo. Aunque los elementos estéticos estén mitigados por el gesto crítico del narrador y el tono de denuncia, estas partes finales permiten el enriquecimiento de la novela porque albergan nuevos discursos no empleados hasta el momento. Incluso la evolución que van a sufrir los epílogos nos dará las claves definitivas para la relectura política e ideológica de Operación Masacre. Son textos necesarios para orientar sobre el proceso judicial debido a que ofrecen las declaraciones de los acusados y notas de prensa mal intencionadas de los diarios oficiales. Walsh aprovecha para denunciar cuestiones de actualidad, como la violencia de Estado, lo absurdo de las guerras o la demagogia de los discursos oficiales. La crítica, acorde con lo que venimos diciendo de esta primera edición, aún será muy parcial, no así cuando se busque desvelar el fraude informativo que proyectan los periódicos más sensacionalistas $^{27}$. La voz narrativa se deja entrever con algunos pasajes autobiográficos, pero en general, la información aportada es excesiva y repetitiva, y los textos se tornan densos y anacrónicos; los nombres de algunos protagonistas, como el doctor Vignone o Marcelo, solo son tangenciales a la historia principal, y sus conferencias e intercambios de acusaciones terminan por confundir al lector.

Dando un salto de continuidad hacia la tercera edición (1969, OM3), se observa cómo, a doce años de distancia del caso, algo ha cambiado en la escritura de Walsh. El epílogo se reduce considerablemente respecto al inicial. El obligado apéndice y sus cuatro capítulos se eliminan, y el epílogo provisorio se establece como casi definitivo. El flujo de datos, fechas, conferencias de presa o testigos secundarios, cede paso a una narración condensada, austera en artificios retóricos a favor de una intención acusadora directa. Aquí la voz narrativa es la del periodista y escritor, pero más aún, la del militante peronista y simpatizante marxista que no

\footnotetext{
${ }^{27}$ Recordamos su vinculación a la crítica arltiana y al desajuste entre la realidad y la circulación de información periodística.
} 
deja espacio para los titubeos, ni para silencios narrativos. Son estos años especialmente políticos en la vida de Walsh, como ya hemos apuntado. Leemos en el epílogo de $O M 3$ :

Tres ediciones de este libro, alrededor de cuarenta artículos publicados, un proyecto presentado al Congreso e innumerables alternativas menores han servido durante doce años para plantear esa pregunta a cinco gobiernos sucesivos. La respuesta fue siempre el silencio. (OM3 192)

Esa respuesta contesta a la pregunta acerca de si los fusilamientos se reconocían como atrocidad autorizada o si fueron desautorizados por el régimen. El tono es mucho menos esperanzador y descarnado del idealismo de los años anteriores; con mayor madurez discursiva y agilidad en la escritura. Por otra parte, la jerga peronista se deja notar sin sutileza. Escribe en el epílogo de $O M 3$ : “[...] los militares de junio, a diferencia de otros que se sublevaron antes y después, fueron fusilados porque pretendieron hablar en nombre del pueblo: más especificamente del peronismo y de la clase trabajadora" (OM3 194). La cursiva es nuestra para destacar cómo se produce ese vaciamiento del campo político que subyace al discurso de Walsh. La fórmula de Perón es efectiva y esta es una de las diferencias fundamentales entre los nuevos paratextos de Operación Masacre y los anteriores. Walsh es ahora peronista y su obra forma parte de la relectura del movimiento por parte de la izquierda ya aludida. La elección de estos sintagmas, que identifican peronismo y clase obrera, se emplean ahora con todo el poder de su significación, y la posición política que implica ${ }^{28}$. Lo mismo ocurre con la irrupción de nombres propios que antes se omitían por decoro, como el general Aramburu, el almirante Rojas, el teniente coronel Fernández Suárez o el jefe de policía Moreno. Aquellos llamamientos a la fe en la justicia son sustituidos ahora, en el epílogo de 1969, por

\footnotetext{
${ }^{28}$ Dentro del cuerpo textual encontraremos la fórmula implícita de peronistas-víctimas-obreros, por ejemplo, en la descripción de la casa de Carranza: "Pero es una casa limpia, sólida, discretamente amoblada, una casa donde puede vivir un obrero" (Walsh, OM4 25).
} 
consideraciones diametralmente opuestas "Era inútil en 1957 pedir justicia para las víctimas de la «Operación Masacre» como resultó inútil en 1958 pedir que se castigara al general Cuaranta por el asesinato de Satanowski [...]. Dentro del sistema, no hay justicia" (OM3 195).

En la cuarta edición de 1972 (OM4), el epílogo se verá ampliado por dos nuevos textos de suma importancia para clausurar de forma definitiva todo el devenir editorial de Operación Masacre. El primero de los textos se titula "Aramburu y el juicio histórico", y aparece numerado como si fuese una continuación del cuerpo textual, aunque esté situado tras el epílogo. Con esa ambigüedad quizás se pretenda ubicar el apartado fuera de una zona textual concreta, para resaltar así su condición de discurso histórico por encima de instancias subjetivas o literarias (ficcionales). Esto explicaría el otro elemento anómalo del capítulo: el sujeto enunciador de primera persona se reemplaza por la tercera. El texto, por tanto, se reviste de crónica histórica y periodística, carente de pasajes autobiográficos ${ }^{29}$. En este capítulo vemos de forma contundente el giro ideológico de Walsh, cuyo discurso está ya lejos de aquellas iniciales palabras en la introducción de la primera edición de 1957 donde se declaraba antiperonista. Además, hay pistas aún más evidentes, como es el aval que se le concede a la militancia guerrillera de los montoneros; la categoría de "héroe" es ahora adoptada por la organización colectiva cuando anteriormente se había erguido sobre la figura del narrador ${ }^{30}$. En ese sentido, aunque sea en tercera persona, el texto vuelve una y otra vez sobre las subjetividades y los guiños autobiográficos. Otro aspecto esencial que nos apunta el texto, aunque solo sea a través de una leve alusión, es cómo se estaba librando estos conflictos de identidad nacional dividida en el seno del campo

\footnotetext{
${ }^{29}$ Dice Rita de Grandis al respecto: “Aramburu y el juicio histórico parece hablar por sí mismo; se articula como un manifiesto político que se atribuye el secuestro y la ejecución del general como un acto simbólico de justicia colectiva" ("Entre la escritura" 116).

${ }^{30}$ Julián Pérez sostiene que el combatiente popular es un ideologema que recorre la literatura argentina del siglo XX que, además, “[...] coincide con el sentido mesiánico de la política peronista" (131). Por tanto, en Operación Masacre, “[...] el periodista se mantiene muy cerca del pueblo trabajador, es parte de él. Es el héroe proletario de la comunidad letrada para quien escribir es un oficio [...]. El pueblo trabajador y el periodista se complementan" (Pérez 115-116).
} 
intelectual. Leemos en el capítulo de "Aramburu..." en OM4: "Dentro de esta perspectiva, es posible que Aramburu, además del monumento gorila, llegue a merecer la cantata de un Sábato futuro" (OM4 196). La cita se refiere a la cantata dedicada a Lavalle en Sobre héroes y tumbas y alude a cómo la muerte de Aramburu ha generado la creación de un mártir de la nación entre un sector de la clase argentina. Walsh busca atacar la condición liberal de Sábato, que había apoyado a la Revolución Libertadora. Como bien apunta Rita de Grandis, con esta frase acusatoria se está buscando una confrontación y, a la vez, una reafirmación de la tradición literaria argentina a través de la óptica del peronismo ("La escritura” 201).

Para finalizar, nos retrotraemos hacia el epílogo de la segunda edición de 1964 (OM2) porque supone la excepción a este incremento de la politización en la zona epilogal. Resulta excepcional por su fuerte tono confesional, más acorde a los prólogos que a los epílogos, y porque, aunque sea anterior a la relectura peronista de la tercera edición, retoma la vinculación, ya apuntada, entre literatura, política y periodismo. En este texto, Walsh analiza los triunfos y fracasos de su investigación. El tono triunfal de la tercera edición podría entenderse como respuesta a los cuestionamientos desesperanzados del epílogo de 1964 aunque el efecto parece más conseguido en el segundo, menos artificial y panfletario. Cuando Walsh cultiva la incertidumbre, lo hace auxiliado por las técnicas literarias y reflexiones sobre la funcionalidad de su escritura. Finaliza así el epílogo de $O M 2$ : "Releo la historia que ustedes han leído. Hay frases enteras que me molestan, pienso con fastidio que ahora la escribiría mejor. ¿La escribiría?” (OM2 144). Tal como afirma Amar Sánchez, el peso del narrador se atenúa debido al balance entre los sistemas referenciales, frente a los anteriores, cuyos resultados atraviesan al narrador ( $E l$ relato 108). Por su parte, Hernáiz apunta que en la edición de 1964 late una doble constitución entre lo "provisorio" del epílogo y lo "obligado" del apéndice, los cuales convergen en la duda del narrador acerca de posibilidad de la negación de escribir la novela (16-17). 


\section{El cuerpo textual. La narratio}

El cuerpo textual es el lugar para la narración de los acontecimientos y las argumentaciones para la defensa del proceso, un "texto enmarcado, relativamente fijo" (Hernáiz 20). La narratio ocupa la mayor parte de Operación Masacre, y se divide en tres partes: "Las personas", "Los hechos" y "La evidencia". Siguiendo la terminología de Genette, vemos cómo el autor usa un nivel extradiegético para narrar las vidas de cada uno de los protagonistas; se distancia, por tanto, de los hechos y a la vez va articulando la figura del narrador, que se comportará de forma distinta a como lo hacía en el prólogo. Sin embargo, no tardamos en observar cómo la voz narrativa se permitirá todas las licencias que estime, cuando quiera o vea necesario introducirse en la diégesis ${ }^{31}$. Esta metalepsis, o transgresión de niveles, se produce en el capítulo del encuentro en la embajada, cuando Torres declara: "Yo lo encontré, por fin, muchos meses más tarde, asilado en una embajada latinoamericana" (OM4 44), afirma el narrador en primera persona. La inclusión del narrador en la historia tiene una función testimonial clara, pues serviría a priori de argumento de autoridad acerca de aquello que se cuenta. No obstante, la estrategia se ve frustrada debido a la perspectiva omnisciente que adopta en otras ocasiones, lo cual contradice las leyes de verosimilitud o el pacto de veracidad. La elección del tipo de narración, y las alusiones explícitas a los datos temporales y espaciales, parecen indicar que se quiere narrar en pasado. Sin embargo, es muy frecuente el uso variado de los tiempos verbales que, aunque con intención pretérita, se mueven a veces entre formas de futuro, cuando quiere expresar dudas, incógnitas en la investigación o premoniciones, o las formas del presente cuando busca simultaneidad entre el tiempo de narrar y el de los sucesos.

\footnotetext{
${ }^{31}$ Es significativo, en este sentido, que ya desde la primera frase del capítulo 1, el narrador comienza su relato rompiendo el horizonte de expectativas creado por el prólogo. Si el narrador-periodista manifestaba su voluntad de contar la verdad -en una novela de no ficción-, el texto tiene un inicio literario: "Nicolás Carranza no era un hombre feliz [...], y es posible algo lo mordiera por dentro. Nunca lo sabremos del todo" (Walsh, Operación [ed. 2008] 23). La alusión al interior del personaje aleja al texto del periodismo tradicional y lo acerca a la novela. Asimismo, el uso del plural mayestático busca la empatía del lector para destacar también la inutilidad de la escritura: por más que se denuncie, su muerte ya es inevitable.
} 
Entre la diversidad de discursos, el estilo directo se deja ver en algunos diálogos entre los personajes con sus familias y amigos. En muchos de estos capítulos, el autor opta por finalizar con un diálogo en estilo directo, como procedimiento que aporta mayor fuerza de verosimilitud a la historia y contribuye a resaltar el enigma ${ }^{32}$. A todas estas definiciones en la elaboración del discurso se suma la focalización cero del narrador -o narrador omnisciente- similar al realismo tradicional, para aclarar quiénes son los personajes y qué piensan, cómo se sienten y cómo se comportarán en actos futuros. Retomamos, por tanto, el permanente conflicto de la escritura de Walsh, oscilante entre una presunción de verdad -como si tuviera toda la información en su poder-y los límites que implica la construcción del relato a través de los testigos. No es casualidad que dos capítulos se titulen "Alarmas y presentimientos" y "Las incógnitas". Encontramos varios ejemplos en el texto de este narrador confuso y entregado abiertamente a la duda ${ }^{33}$.

Esta literaturización afecta a la figura del narrador y a los personajes en partes iguales. Al narrador, porque encubre sus fuentes de información periodísticas y documentales. Las encubre, es decir, decide omitirlas y fingir que, como narrador omnisciente, las sabe de forma innata. La literaturización de los personajes, precisamente a través de las técnicas del narrador, promueve que los percibamos como seres ficticios, construidos, y olvidemos casi que remiten a personas reales, alejando la novela de su carácter de no ficción. Si bien Philipe Lejeune apunta que, en la no ficción, se establece un pacto entre autor y lector según el cual el orden del relato no requiere de una exacta semejanza con la verdad, lo cierto es que la literaturización de hechos y personajes lleva al lector a desconfiar de la veracidad que rige la no ficción. Con esta lógica, se explica también que la estructuración y

\footnotetext{
${ }^{32}$ No incidiremos más en este apartado en torno al recurso del suspense, pues ya se apuntaron las reminiscencias folletinescas debido al carácter seriado de la primera publicación de la novela.

${ }^{33}$ También veremos esta técnica en el vaivén entre la seguridad y la incertidumbre: "Sabemos por ejemplo que alrededor de las 21 aparece un hombre llamado Rogelio Díaz pero no sabemos con exactitud quién lo trae (...). Sabemos que vive muy cerca de allí pero ignoramos si es esa simple proximidad lo que explica su presencia. [...] ¿Está comprometido con el movimiento revolucionario? Puede ser. También puede ser que no" (Walsh, Operación [ed. 2008] 41). Esta estrategia retórica, además de generar intriga, incide en la arbitrariedad del crimen: se asesina a alguien sin conocer su postura ideológica.
} 
disposición de estos capítulos no sigan el orden que imponía la investigación. Según Bárbara Crespo, el orden de los capítulos de $O M 1$ se estableció según el grado de compromiso político de los protagonistas, de mayor al menor (De Grandis, "Entre la escritura" 196). En las sucesivas ediciones, en cambio, los capítulos se desordenan. Por otro lado, esa "exacta semejanza con la verdad" aludida por Lejeune tampoco se cumple desde el momento en que el autor quiere buscar la manera más personalizada e idónea para describir a cada protagonista con el fin de despertar la empatía al lector y al auditorio. Tal empatía responde a un interés claramente político: alcanzar una compenetración entre lector y pueblo peronista. Por ejemplo, cuando se posiciona al lector en contra de la Revolución Libertadora mediante alusiones a la misma como la siguiente: "Después ya se sabe lo que ocurre. Una ola revanchista sacude al país" (Operación [ed. 2008] 43). Al decir "ya se sabe", el narrador busca su complicidad y da por hecho que el lector es conocedor de los acontecimientos. Los personajes, víctimas de la Revolución Libertadora, representan así al pueblo peronista, sobre todo, a partir de las declaraciones en los paratextos de la última edición.

Dichas reflexiones llevan a plantear cuál es el lector ideal de la novela ${ }^{34}$. En este sentido es pertinente preguntarse a quién va dirigido la edición final de Operación Masacre. La respuesta implícita, que se deduce de la evolución del texto y paratextos, es al pueblo argentino, el cual es peronista a partir del vaciamiento del campo político. Ello, en consecuencia, nos induce a preguntarnos si la novela de Walsh tiene la capacidad de adquirir un alcance internacional o si es un producto de consumo nacional interno. Si bien es cierto que toda manifestación artística puede tener nuevas lecturas fuera de su contexto, no es arriesgado admitir que una novela de no ficción que denuncia un acontecimiento histórico concreto no es importable a otros ámbitos. A este respecto, Rama se posiciona a favor de la universalidad de Operación Masacre, postura que nosotros no compartimos. No

\footnotetext{
${ }^{34} \mathrm{El}$ lector ideal es una abstracción de aquel lector que comparte los mismos códigos de lectura que el escritor y que, por tanto, es capaz de extraer todos los sentidos potenciales del texto (Iser 5758).
} 
negamos, empero, que la novela sea comprensible por un público foráneo gracias a las estrategias de intriga indicadas por $\mathrm{Rama}^{35}$; pero nuestra hipótesis parte del lector ideal que el propio texto parece reclamar.

En "La evidencia" se disminuye la frecuencia de los usos literarios a favor de una vuelta al discurso periodístico y judicial. El narrador, que se metamorfosea de escritor-autor a periodista y activista político, se transforma en fiscal del proceso y hasta en juez de la última sentencia. Los tres capítulos se pueblan de documentos, pruebas, declaraciones, acusaciones, desmentidos, fallos judiciales y códigos legales de todo tipo. Walsh utiliza la técnica de "probación por argumentación" pero también por acumulación y repetición continua de una idea fija: la ilegalidad y arbitrariedad de los fusilamientos. Véase en la siguiente cita: "Sin causa, en efecto, se había pretendido fusilar. Sin causa, se le había torturado moralmente hasta los límites de la resistencia humana. Sin causa, se le había empujado a la locura. Sin causa, se le había condenado al hambre y la sed" (Operación [ed. 2008] 167). Los dos centros de la diana van a ser: Fernández Suárez, como responsable directo de activar la orden de fusilamiento; Rodríguez Moreno, por aplicarla; y el Estado personificado en Aramburu, su equipo de gobierno, militares y jueces, por proporcionar una única respuesta: el silencio institucional. Pese a la frustración de no poder restituir la injusticia cometida, como el mismo Walsh reconoce, el texto arriesga a desvelar el verdadero reto, el metalingüístico, las limitaciones de la escritura, y, por tanto, poner en evidencia su propia problemática interna. El mensaje final sería, paradójicamente, destacar la inutilidad de la literatura de denuncia si la obra se reduce a una mera lectura. La literatura de compromiso espera del lector el paso del texto a la praxis social ${ }^{36}$, como lo será la carta escrita por Walsh a la Junta Militar en 1977. Véase el siguiente ejemplo de la novela:

\footnotetext{
${ }^{35}$ Rama: "Seguramente, para un lector alejado de los sucesos políticos y sindicales argentinos, que ignora quién es Livraga, [...] la lectura [...] conservará igual validez, al margen de su correspondencia con hechos reales, y aun alcanzará la intensidad y el suspenso de una excelente policial" (299).

${ }^{36}$ Retomamos la declaración de intenciones en la introducción a la primera edición omo ejemplo de ello: "Reitero que esta obra no persigue un objetivo político [...]. Persigue -una entre muchas- un objetivo social: el aniquilamiento a corto plazo de los asesinos impunes" (OM1 16).
} 
Aquí quiero pedir al lector que descrea de lo que yo he narrado, que desconfíe del sonido de las palabras, de los posibles trucos verbales a que acude cualquier periodista cuando quiere probar algo, y que crea solamente en aquello que, coincidiendo conmigo, dijo Fernández Suárez. Empiece por dudar de la existencia misma de esos hombres a los que, según mi versión, detuvo el jefe de policía en Florida, la noche del 9 de junio de 1956. Y escuche a Fernández Suárez ante la Junta Consultiva el 18 de diciembre de 1956, según la versión taquigráfica[...]. (Operación [ed. 2008] 180)

La cursiva es nuestra para indicar cómo la metalepsis funciona aquí para intentar convencer al lector, a quien el narrador convierte en una suerte de jurado, y conseguir su implicación futura en la política de su país ${ }^{37}$. Se observa aquí el tono irónico de quien sabe que esa versión taquigráfica, de pretensión objetivista, revelará su condición de mentira construida. Se ha dejado constancia de la manipulación del discurso, tanto en un bando como en otro o, en términos de Piglia $^{38}$, de los mecanismos de ficción del Estado contra los cuales deben luchar las versiones de los oprimidos silenciados. Walsh reitera que tal ficcionalización existe tanto si no se tiene problemas en desvelarla como si hay intereses en encubrirla. Pensamos, por tanto, que el escritor privilegia ciertas estrategias discursivas sobre otras a la hora de aportar esa legitimidad al relato. En otras palabras, si bien busca desmantelar la ficción del Estado, parece conceder una sutil sobrestimación a los discursos fingidamente objetivistas, científicos. O, si no cree en ellos desde la óptica tradicional, sí cree en su capacidad de provocar un efecto de veracidad. Por ello acude, de forma excesiva, a la reproducción fidedigna de los documentos: las

\footnotetext{
${ }^{37}$ En palabras de Piglia: "En esa línea, Walsh define a su lector como el que disputa con el narrador. [...] El efecto de la ficción [...] depende de la recepción; en todo caso, depende de un tipo de lectura" (Las tres vanguardias 185). Sirva la siguiente cita para ilustrar cómo el narrador emplea su texto como evidencia: "Conste aquí. Consten las ventajas que da el alfabeto para martirizar a una pobre mujer" (Walsh, Operación [ed. 2008] 153).

${ }^{38}$ En Tres propuestas para el nuevo milenio (y cinco dificultades) (2011).
} 
versiones telegráficas o taquigráficas, y los fallos de las sentencias en sus claves legalistas. No queremos decir con esto que Walsh infravalore el discurso literario o crea en la iluminación del lenguaje de la justicia; al contrario, es precisamente el juego de visibilidad/ocultamiento, la paradoja irresoluble de la mezcla que se opera en el género de no ficción, lo que le permite problematizar el camino hacia la verdad.

\section{Conclusiones}

Operación Masacre responde simultáneamente a distintos cambios que se estaban fraguando en el terreno literario, intelectual y político a partir de la década de los cincuenta en Argentina. El empleo de la literatura policial fue un proceso iniciado por Borges y Bioy Casares en la década anterior, quienes acercaron un género de origen popular a la cultura de élite. Walsh parte, pues, de un género ya instalado en el centro del sistema literario, pero hace un uso distinto de él; su interés se aleja de la mera experimentación formal de los escritores mencionados para denunciar un acontecimiento político y señalar al Estado como responsable del mismo. Walsh no conjuga alta y la baja cultura al elegir el género policial, como así lo hiciera anteriormente la dupla Borges-Bioy, pero revierte su mensaje político. $\mathrm{Si}$, según la tesis de Avellaneda, el policial era un cauce para desmantelar al Estado peronista durante los cuarenta, Walsh invierte esa operación porque el peronismo deviene víctima del Estado a partir de 1955. Su intención de denuncia lo lleva además a escoger otras modalidades genéricas ajenas a la literatura canónica -el periodismo y la no-ficción- debido a su eficacia para la denuncia, adelantándose así a escritores posteriores, como Capote.

A pesar de que el uso de las tres modalidades - policial, periodismo y noficción- se mantiene en todas las versiones de la novela, los cambios de sus paratextos sí muestran la evolución de la ideología política del escritor a favor del peronismo. El acercamiento a dicha doctrina se explica a partir del surgimiento de un nacionalismo de izquierdas. La fórmula Perón-pueblo-Argentina deja de ser exclusiva de los peronistas de la primera hora para ser utilizada por intelectuales de 
izquierdas. Walsh no proyecta su conciliación con el peronismo únicamente en los prólogos posteriores sino que, en el cuerpo del texto, perfila al trabajador o al obrero como representantes del pueblo argentino (peronista), víctima de la Revolución Libertadora. De esta manera, se observa cómo la realidad política ingresa en la ficción mediante la caracterización genérica de Operación Masacre -la no-ficción, el periodismo y el género policial-, a través de sus paratextos y de la persuasión de un narrador que, como hemos visto, busca la complicidad de un lector-jurado que se posicione a favor del peronismo como víctima. De ahí nuestra conclusión al considerar que Operación Masacre es una novela de consumo interno que requiere conocer su contexto histórico-político para su plena comprensión.

\section{Bibliografía}

Amar Sánchez, Ana María. "El sueño eterno de justicia". Nuevo Texto Crítico, vol. VI, no 12-13, 1993-1994, pp. 205-218. . El relato de los hechos, Rodolfo Walsh: testimonio y escritura. Ediciones de la Flor, 2008.

Avellaneda, Andrés. El habla de la ideología. Sudamericana, 1983.

Badiou, Alain. El siglo. Manantial, 2005.

Borges, Jorge Luis. "Una efusión de Ezequiel Martínez Estrada". Sur, nº 242, 1956, pp. 72-73.

Brecht, Bertolt. El compromiso en literatura y arte. Península, 1984.

Ferro, Roberto. "Operación Masacre: investigación y escritura". Nuevo Texto Crítico, vol. VI, no 13-14, 1993-1994, pp. 139-166.

Ford, Aníbal, "Walsh: la reconstrucción de los hechos". Nueva novela latinoamericana 2, p. 240. Paidós, 1974.

García, Victoria. "Las reescrituras de Operación Masacre". Estudios filológicos, $n^{o}$ 63, 2019, [s.p.]. 
Genette, Gérard. Ficción y dicción. Lumen, 1993.

Gilman, Claudia. Entre la pluma y el fusil, debates y dilemas del escritor revolucionario en América Latina. Siglo XXI Editores, 2003.

Gramuglio, María Teresa. "La construcción de la imagen”. La escritura argentina, p. 37-64. Universidad del Litoral, 1992.

Grandis, Rita de. "Entre la escritura del acontecimiento y el acontecimiento de la escritura". Polémica y estrategias narrativas en América Latina, J. María Arguedas, Mario Vargas Llosa, Rodolfo Walsh, Ricardo Piglia. Beatriz Viterbo Editora, 1993. . "La escritura del acontecimiento: implicaciones discursivas". Nuevo Texto Crítico, vol. VI, no 12/13, 1993-1994, pp. 187-204.

Hernáiz, Sebastián. Rodolfo Walsh no escribió Operación Masacre y otros ensayos. 17g Editora, 2012.

Iser, Wolfgang. El acto de leer: teoría del efecto estético. Taurus, 1987.

Jitrik, Noé, "Bipolaridad en la literatura argentina". Cuadernos de crítica, nº 2, 1965, pp. 24-42.

Jozami, Eduardo. Rodolfo Walsh. La palabra y la acción. La Página/ Norma, 2011.

Lejeune, Philipe. El pacto autobiográfico. Editorial Antrophos, 1991.

Link, Daniel. Ese hombre y otros papeles personales. Ediciones de la Flor, 2007. . Rodolfo Walsh. El violento oficio de escribir, obra periodística (19531977). Ediciones de la Flor, 2007.

Louis, Annick. “¿Por qué escribir un libro? Las versiones de Operación Masacre de Rodolfo Walsh". Exlibris, n5, 2016, pp. 394-406.

Martínez Estrada, Ezequiel. “Grandeza y miseria de los escritores”. Propósitos, n⿳o 135-137, 1956.

Panesi, Jorge, "Borges nacionalista”, Filología Hispánica: https://filologiaunlp.files.wordpress.com/2011/08/borges-nacionalistapanesiparadoxa7.pdf (última visita el 28/02/2019). 
Pérez, Alberto Julián. Literatura, peronismo y liberación nacional. Corregidor, 2014.

Piglia, Ricardo. Tres propuestas para el nuevo milenio (y cinco dificultades).

Fondo de Cultura Económica, 2011.

. Las tres vanguardias. Saer, Puig, Walsh. Eterna Cadencia, 2016.

Rama, Ángel. "Rodolfo Walsh: el conflicto de culturas en Argentina”. Escrituras: teoría y críticas literarias, $\mathrm{n}^{\mathrm{o}} 2$ 2, 1976, pp. 279-301.

Sigal, Silvia y Eliseo Verón. Perón o muerte. Los fundamentos discursivos del fenómeno peronista. Eudeba, 2010.

Viñas, David. Literatura argentina y política. II. De Lugones a Walsh. Santiago Arcos Editor, 2005.

Walsh, Rodolfo. Operación Masacre: un proceso que no ha sido clausurado, Ediciones Sigla, 1957.

. Operación Masacre y el expediente Livraga: con la prueba judicial que conmovió al país, Ediciones Continental Service, 1964.

. Operación Masacre. Ed. Jorge Álvarez, 1969.

. Operación Masacre. Ediciones De la Flor, 1972

. Operación Masacre. 451, 2008.

. "El periodismo y el arte burgués" [entrevista con Ricardo Piglia, 1970], Anfibia : http://www.revistaanfibia.com/cronica/el-periodismo-y-el-arteburgues/ (última visita el 25/07/2018). 